\title{
The Proceedings of the International Conference
}

on Creationism

Volume 8

Print Reference: Pages 255-267

Article 36

2018

\section{Devotional Biology: A Young-age Creationist, College-level, Conceptual Biology Textbook}

Kurt P. Wise

Truett McConnell University

Joseph W. Francis

The Master's College

Neal A. Doran

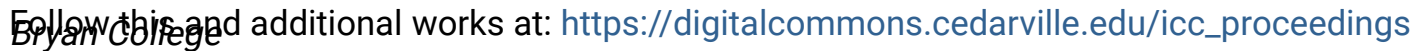

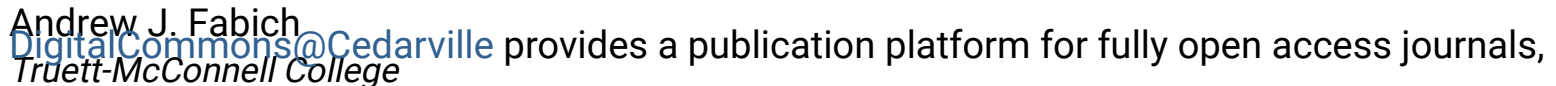
which means that all articles are available on the Internet to all users immediately upon Stepplamienthardzever, the opinions and sentiments expressed by the authors of articles BCyâiskellegfe our journals do not necessarily indicate the endorsement or reflect the views of DigitalCommons@Cedarville, the Centennial Library, or Cedarville University and its employees.

Ske a dc@cedarville.edu.

Browse the contents of this volume of The Proceedings of the International Conference on Creationism.

\section{Recommended Citation}

Wise, K.P., J.W. Francis, N.A. Doran, A.J. Fabich, S. Hartz, and T. Hennigan. 2018. Devotional Biology: A young-age creationist, college-level, conceptual biology textbook. In Proceedings of the Eighth International Conference on Creationism, ed. J.H. Whitmore, pp. 255-267. Pittsburgh, Pennsylvania: Creation Science Fellowship. 
Devotional Biology: A Young-age Creationist, College-level, Conceptual Biology Textbook

\section{Authors}

Kurt P. Wise, Joseph W. Francis, Neal A. Doran, Andrew J. Fabich, Stephanie Hartz, and Tom Hennigan 


\section{DEVOTIONAL BIOLOGY: A YOUNG-AGE CREATIONIST, COLLEGE-LEVEL, CONCEPTUAL BIOLOGY TEXTBOOK}

Kurt P. Wise, Truett McConnell University; Pilgram Marpeck School of STEM; 100 Alumni Dr.; Cleveland, GA 30528

kwise@truett.edu

Joseph W. Francis, The Master's University, 21726 Placerita Canyon Rd; Santa Clarita, CA 91321

Neal A. Doran, Bryan College, 721 Bryan Drive, Box 7795; Dayton, TN 37321

Andrew J. Fabich, Truett McConnell University; Pilgram Marpeck School of STEM; 100 Alumni Dr.; Cleveland, GA 30528

Stephanie Hartz, Bryan College; Department of Biology; 721 Bryan Drive, Dayton, TN 37321

Tom Hennigan, Truett McConnell University; Pilgram Marpeck School of STEM; 100 Alumni Dr.; Cleveland, GA 30528

\section{ABSTRACT}

Devotional Biology is being developed as a one-semester college-level conceptual biology textbook for non-science majors. Except for presenting a survey of organisms and an introduction to organismal anatomy and physiology (typically reserved for a second-semester course), Devotional Biology covers all the major topics of biology presented in secular texts as well as a few others not usually covered at all. Student surveys indicate students believe they learn biology through the Devotional Biology text. At the same time, Devotional Biology presents biology from the perspective of a distinctly biblical worldview - and on surveys, Devotional Biology students believe they improved their appreciation of biology as well. Devotional Biology also focuses on God, and how His attributes are evident in the biological world - and on surveys, Devotional Biology students believe they improved their recognition of God in the creation, their understanding of God, their relationship to God, and their use of the creation in witness to others. Devotional Biology also assumes a young-age creationist interpretation of biology, critiquing the naturalistic perspective of the field in the process - and on surveys, Devotional Biology students believe they grew in their faith and learned to defend their faith. Devotional Biology also includes responsibilities of believers as priests and kings in God's creation - and on surveys, Devotional Biology students believe they grew in their understanding of their ethical responsibilities, in their worship of God, and in better ruling over the creation.

\section{KEY WORDS}

college, textbook, conceptual biology, biblical worldview, young-age creationism, holism, macro-to-micro

\section{INTRODUCTION}

This textbook grew out of the experiences of one of the authors of this paper (KPW). In the Fall of 1989, after formal education through a Ph.D. of an entirely secular nature, KPW assumed a position teaching biology at a Christian college. In a faculty workshop prior to the beginning of classes, the faculty were challenged to teach each of their respective disciplines from a biblical worldview. KPW found the rationale for the challenge compelling, but without any training in a biblical worldview, he knew little to nothing about what a biblical worldview looks like in biology. By the very nature of a worldview, he realized that it must involve something more foundational and permeating than just a creationist interpretation of historical biological data. So, as any good junior faculty member, he asked the head of the department for sources on a biblical worldview of biology, and tips on how to teach biology from such a perspective. The response was not satisfactory. In fact, searching science textbooks and both creationist and worldview literature, surprisingly little was found on how to teach biology from a biblical worldview.

Down through the centuries, Christians have contributed to the discipline of biology. Yet, most of the pieces that make up modern biology were contributed by naturalistic biologists and those pieces were woven together almost exclusively by biologists with a naturalistic worldview. The philosophical foundations of biology, as presented in textbooks, are fundamentally naturalistic in nature. The nature of reality, the nature and value of truth, the purpose of science, the nature of science, the definition of biology, the history of biology, the definition of species, the definition of higher taxa, the purpose of biosystematics, the biosystematic method(s) all these things and many more are generated from a naturalistic perspective. Existing Christian biology textbooks interpret the content of secular biology texts through a biblical lens, and some of them do a pretty good job of that. The problem is that this promotes the incorrect notion that the study of the physical world (science) is in one realm and must be viewed from the perspective of another realm - the realm, for example, of the Bible. God's word and God's world are revelations of the same God, and their respective studies should not be so divided. A biblical worldview of biology is not generated by interpreting secular biology through a biblical lens. A biblical worldview of biology must start with a different perspective of reality and truth, and from that perspective, generate distinctly biblical purpose and method. Everything in biology is different in a biblical worldview. Perspectives on how life began, what life is, what life is for, and where life is going are all different, as are perspectives on how humanity began, where it is going, why it is here, and what its responsibilities are to the rest of the world. A truly biblical biology text must unravel the entire discipline of biology and build it anew. 
After teaching biology on a college level in Christian schools for over 20 years, KPW finally made a first attempt at creating a biology textbook with a biblical worldview perspective. By no means does he claim to have achieved his goal. He hopes, however, that he has inched closer to that goal. A truly biblical perspective of biology would require a biblical epistemology of science, a biblical philosophy of science, and a synthetic creationist biology. None of those things exist at this point in time. For the sake of young people being trained even more soundly in a biblical worldview of biology, we pray these disciplines are developed and integrated into our textbooks, and that this happens sooner rather than later.

This paper purposes to review the content of KPW's text (Devotional Biology), explain how it has been used, and present data on its impact on students.

\section{THE DEVOTIONAL BIOLOGY TEXT}

KPW authored Devotional Biology as a textbook for a one-semester, college-level, conceptual biology course. He composed the first rough draft in the academic year of 2011/12 as he taught such a course at Truett-McConnell College (as of 2016, Truett McConnell University). Since then, the text has been revised multiple times, especially after review by two theologians and four biologists from different academic institutions. Since the Fall of 2012, the text has been printed and spiral bound by the Truett McConnell bookstore. Besides revisions of the original text, questions and an appendix critical of naturalistic evolution were added in the 2012 edition, chapter summaries were added in 2013, and a glossary was added in 2015. Future additions will include more illustrations, more references, and a second appendix critical of theistic evolution. Supplementary material includes a lab manual developed in association with the original text in 2011, lecture videos created for an online course in 2013, PowerPoints added in 2014, a test bank added to the online course in 2015 , and lecture videos, test bank, lab manual, and lab kit revised for a homeschool course in 2017.

\section{Topics}

Devotional Biology focuses more on the concepts of biology than it does on the details of biology that are believed foundational for training a professional biologist. Thus, Devotional Biology is designed as a biology text for the college student who is not a biology major - i.e., it is a 'conceptual biology' or 'general biology' text. It should be noted, however, that because Truett McConnell University values the biblical worldview, all their students are required to take the course that uses Devotional Biology as its text—even the biology majors.

Typical of conceptual or general biology texts of a secular nature, Devotional Biology introduces the reader to the nature of science, the nature of life, inorganic and organic chemistry, DNA structure and function, the origin and diversification of life, cell theory, cell structure, cell metabolism (especially photosynthesis and aerobic respiration), cellular reproduction (especially mitosis and meiosis), Mendelian genetics, life's nested hierarchal classification, biodiversity, animal behavior, community ecology, ecosystems (including biogeochemical cycles), biodiversity, and biomes. Devotional Biology does not cover plant or animal anatomy or physiology and it does not survey life's diversity. These are rather typical topics of a second semester of biology for non-majors.
Devotional Biology is thus an appropriate textbook for a semesterlong course when that is the only conceptual biology course a college offers, or it is an appropriate textbook for the first semester of a two-semester non-majors biology sequence (with another textbook required for the second semester).

There are a number of patterns and concepts in biology that are difficult to explain by naturalistic evolution. It is not surprising that such things rarely get included in introductory biology textbooks. If they are discussed at all, they are usually relegated to upperlevel courses as intellectual challenges. Several of these topics are readily explained in a creationist perspective of the world. For this reason, Devotional Biology introduces the reader to several additional topics not generally found in secular biology texts (e.g. the presuppositions of science, the anthropic principle, biological beauty, biological discontinuity, and biological disparity). A few more topics (which become especially important in a young-age creationist perspective of the world) are given substantially more emphasis in Devotional Biology than is typically encountered in secular texts (e.g. biological (natural) evil, baramins and baraminology, and the biomatrix).

\section{Perspectives}

More fundamental than the major topics covered in the text, Devotional Biology has a suite of perspectives which markedly distinguish it from other biology textbooks - even, in some cases, other Christian or creationist biology textbooks.

\section{A. Biblical Worldview}

Devotional Biology is up-front and non-apologetic about its biblical worldview. In the wide spectrum of worldviews that are available, the text consistently applies only two worldviews to biology - naturalism and Christian theism. Naturalism is included because this worldview dominates biology and biology textbooks, so it is a worldview with which every student of biology should be familiar. Yet, because it is not the worldview of the author, the naturalistic worldview perspective of each topic is not even mentioned until the Christian theistic view has been fully presented and explained. And then, naturalism is almost always critiquedin chapter after chapter shown to be inadequate to explain the major characteristics of biology. In contrast, the text clearly advocates a Christian theistic perspective. And it is important to note the worldview advocated is not just a theistic worldview, it is Christian theistic worldview. One of the main themes of the text is that God illustrates His invisible nature through the physical creation. Not only is this concept clearly taught only in the New Testament, but only the Christian God is so desirous of relationship with humans that He would make the universe that way. Furthermore, whereas the Triune God provides an explanation for the diversity and hierarchy of life, a monistic god, such as is worshipped in modern Judaism and Islam, does not explain the hierarchy and extreme diversity of life. Consequently, the Devotional Biology text is not only unacceptable in secular academia, it would be unacceptable in Jewish and Muslim academic environments.

Thus, the worldview perspective of Devotional Biology is much more specific than Christian theism. Devotional Biology adopts a conservative Christian position, upholding a very high view of Scripture. Devotional Biology accepts Scripture as truth, and its 
individual claims as truth claims-i.e., data. Just as descriptions of the physical world are considered data in secular science, the truth claims of Scripture are considered data as well. In fact, since the physical world makes no claims of objective truth at all (these must be deduced by humans), and Scripture does, Scripture is the first place we should go for data. Devotional Biology takes this approach, and in this sense it can be said to have a biblical worldview. Devotional Biology begins its study of biology with the Bible and its claims about biology, and consults with Scripture all along the way. Christian traditions that put less truth value in Scriptural claims will not be comfortable with Devotional Biology.

Most biology texts will never mention the presuppositions of science. It is the biblical worldview of Devotional Biology that explains why it discusses the presuppositions of science. It is only the Christian God Who would create the world in such a way that humans could know Him. And for that to happen, the world and humans had to be specially designed so that humans could study and learn from that world. Those special designs (order, unchanging laws and processes, comprehensible design and sufficiently complex human brain, correspondence of universe design and human language, etc.) turn out to be the presuppositions of science- the very things that make science (and biology) possible. Thus, it is creation by the Christian God that explains why science exists, why science works, and why we should study it.

\section{B. God-Centered}

As mentioned above, Devotional Biology starts with Scripture. Scripture starts with God (Gen. 1:1). In fact, Scripture starts and ends with God, and centers on God. God preceded the biological world. The biological world came into existence because of God and the biological world continues to exist only because of God. In fact, Romans 1:18-19 indicates that God created the physical world in such a way that it contains physical illustrations of the invisible attributes of God so that humans could 'see' those invisible attributes. Therefore, one reason the biological world was created, was to illustrate the invisible nature of God. Based on this, Wise (2005) suggested that the nature of God we learn from Scripture could be used to better understand the created world, and also to organize the study of that world. This becomes one of the primary organizational themes of Devotional Biology - the middle thirteen of the fifteen chapters begin with an attribute of God derived from Scripture, and then turn to the biological world to determine how biology illustrates that attribute (biological life illustrating God's life, biological discontinuity illustrating God's distinctness, biological mutualism illustrating God's goodness, animal behavior illustrating God's personhood, the anthropic principle illustrating God's love in provision, biogeochemical cycles illustrating God's love in sustenance, monomers and biological systems illustrating God's unity, biological diversity and disparity illustrating the Trinity, netted hierarchy [Wise 1998] illustrating God's unified hierarchy, communication and DNA illustrating God's word, and reproduction and diversification and biogeography illustrating God's fullness). It is for this reason that these thirteen chapters are titled with attributes or descriptions of God ('The Living God', 'The Glory of God', 'God is Distinct', 'God is Good', 'God is Person', 'Provider God', 'The Sustaining God', 'God is One',
'God is Three', 'God of Hierarchy', 'The Almighty God', 'God the Word', 'Fullness of God'). Since the first chapter explains how biology can be used by the believer to better know and serve God, and the last chapter shows how the history of the biological world mirrors the history of God's interaction with humans, Devotional Biology begins and ends with God and focuses on God throughout. Most biology texts focus on organisms and/or people who study them, and this is reasonable, given that organisms are spectacular and there have been a host of biologists worth learning about. However, Devotional Biology focuses on Someone even greaterthe One Who created both man and organisms.

Besides providing physical illustrations of God's invisible nature, Wise (2015, pp. 38-40) also introduced the 'spectrum of perfection' concept. God's invisible attributes are in some sense or another infinite. If God desired us to understand his invisible attributes, it seems reasonable to assume $\mathrm{He}$ also wanted us to understand their infinitude. Wise (2015, pp. 38-40) suggests that for each of these infinite attributes, God did not just create physical illustrations, He created many physical illustrations. And, God had each unique illustration picture a distinct degree of perfection of that attribute, so that the collage of illustrations produces a 'spectrum of perfection' of that attribute. At the same time, God created humans with the natural tendency to notice that spectrum of perfection and arrange the illustrations in a linear fashion from illustrations with no amount of that attribute to illustrations that contain the greatest perfection of that attribute. Simultaneously, God created humans with a natural tendency to extrapolate beyond the observed spectrum of perfection toward something with an infinite measure of that attribute - i.e., towards God Himself. Thus, not only do most chapters of Devotional Biology refer to physical illustrations of God's invisible attributes, but most chapters also refer to biological spectra of perfection illustrating the infinite character of God (e.g. the spectrum of perfection of biological beauty illustrating God's infinite glory, the spectrum of perfection of biological mutualism illustrating God's infinite goodness, the spectrum of perfection of biological communication illustrating God as the infinite Word, etc.).

The divine illustration perspective of Devotional Biology leads to markedly different interpretations of several areas of biology than seen in traditional biology textbooks. For example, whereas most biology texts fail to address the question of the nature of life itself, creation by a non-material God of life permits discussion in Devotional Biology of the likely non-physical nature of life. Secondly, whereas most biology texts fail to address the question of biological evil, creation by a good God almost demands discussion of the post-creation origin of natural evil. Thus, Devotional Biology discusses the origin of biological evil and the curse of Genesis 3. Fourth, whereas most biology texts may mention some of the 'fortuitous' niceties of this universe for life, they will not discuss the possibility that they actually are designs. Devotional Biology, on the other hand, is free to discuss the anthropic principle and its most obvious explanation (that the universe did not just look like it was created for man, it really was created with humans in mind). Finally, whereas most biology texts discuss the structure and function of DNA and those associated phenomena with communication-related names (e.g., genetic code, transcription, 
messenger RNA, translation), the role of language in the most basic functions of life is not often discussed. Given creation by a communicating God, Devotional Biology is free to discuss the language of life.

\section{Creationism}

Devotional Biology also adopts a creationist perspective of biological origins. In nearly every chapter, the text claims that naturalistic processes are unable to explain the major themes of biology, whereas creation by the God of Scripture does. Examples of critiques of naturalistic evolution from Devotional Biology include: (1) Unguided natural processes are not expected to produce the fine-tuning we see in the universe - not just the finetuning necessary for life, but the fine-tuning that allows humans to study and understand the universe; (2) In principle, physical processes cannot generate non-physical phenomena such as life, consciousness, emotion, will, humor, and self-awareness; (3) Neither natural processes nor human ingenuity has been able to create life or bring back to life any organism that is truly dead, nor generate anything as complex, efficient and microscopic as cellular metabolism; (4) Since, in our experience, life only comes from life, and no living cause is permitted in abiogenesis, the origin of life by abiogenesis requires processes outside of our experience; (5) In our experience, high complexity, elegance, and complex emergent properties only arise due to an intelligent designer. Yet, naturalistic evolution denies the existence of an intelligent designer in earth's early history, so the origin of the elegant and collectively complex biogeochemical cycles, the complex emergent properties of biological systems, and the elegant and irreducibly complex metabolic systems and cells requires evolutionary processes outside of our experience; (6) Since, in our experience, language only arises from communicating beings, and naturalistic evolution denies the existence of a communicating being while life was coming to be, the language evident in human language, animal communication, programming of instinct, and the genetic language of DNA require evolutionary processes outside of our experience; (7) Since evolution in modern theory operates in a stepwise fashion, irreducible complexity (as in biological systems, cells, and cellular reproduction) seems impossible to explain by naturalistic evolution; (8) Evolution in modern theory operates too slowly to explain the large amount of disparity we see in the modern biological world; (9) The tree-like branching expected in biological evolution fails to explain discordances in similarity trees, homoplasies, and unclassifiable mosaics; (10) In a biological world ruled by natural selection, beauty and mutualism should be rare, and pathology should be dominant, but in our earth's biology the opposite is true on both counts; and (11) Biological evolution lacks mechanisms to explain the origin of distinct varieties, breeds and cultivars (morphological information always hidden in natural populations), the maintenance of distinctions between species connected by long-lasting hybrid zones, and the commonness of parallelism and convergence in the modern biological world.

Yet, Devotional Biology does not merely adopt a creationist perspective, it embraces a young-age creationist perspective. This is most markedly evident in chapter five's discussion of the origin and nature of natural evil (as a consequence of the curse of Genesis 3 ), and chapter fifteen's survey of the history of life (which includes creation, fall, global flood, and Babel dispersion). Also according to Devotional Biology, widespread inter-specific hybridization, rare pathology, low mutational loads, and the existence of vestigial organs and genetic throwbacks from old strata all indicate that life is young. The young-age creationist perspective of Devotional Biology would make the text objectionable to all but a very few institutions of higher learning.

\section{Holism}

Naturalistic biologists are reductionists almost by necessity. Naturalism denies purpose, designer, creator, and even nonmaterial essences to guide or stimulate biological change. Natural processes cannot produce non-physical entities and they can produce only very mild complexity. At best, naturalists expect emergent properties to be rare. Consequently, naturalists have every reason to believe that a full understanding of the components of natural objects provides a full understanding of those objects. Thus, it is not surprising that secular biology texts tend to arrange their topics from the micro to the macro, from atoms and molecules in the second chapter (after the required 'What is science?' and 'What is life?' chapter) to communities and biomes in the last chapters. Devotional Biology takes the opposite approach.

Since God is the starting point, ending point, and continued focus of Christian thought, the biblical worldview is inherently holistic. God is the 'biggest' thing there is, God created everything else that exists, God sustains everything that exists, and God defines the purpose for everything. Devotional Biology, then, assumes a holistic perspective of biology. It does this in its focus on and continual reference to God, and it does this by beginning each chapter with a discussion of God's nature, and ending each chapter with our responsibility to God. But Devotional Biology also does this in its arrangement of chapters, dealing first with things readers are most familiar with (the life of organisms, and the beauty of the biological world), and relegating discussion of atoms and molecules until almost half-way through the text.

\section{E. Ethics}

The final distinguishing perspective of Devotional Biology is its focus on Christian responsibility. Chapter one not only provides reasons for why all Christians should study biology, it also makes the Christian aware of responsibilities believers have with respect to the creation. Devotional Biology argues that humans were created in the image of God so as to be priests and kings over the creation. In the Old Testament, priests were called to continually grow in their relationship with God, fill their lives with worship of God, fill the temple with worship of God, and bring others into that worship. Likewise, all believers have been called to continually grow in our relationship with God (through, among other things, their study of God's creation), fill their lives with the worship of God, and bring others into that worship. At the same time, they have been called to rule over the creation. Stewards were given the belongings of their masters to protect and enhance those belongings, being always ready to give account for how well they took care of their master's belongings. So, also, we have been given the creation of God to protect and enhance that creation's glorification of God. As the exemplary kings of the Old Testament were shepherd kings who devoted themselves to the service of both their God and their subjects, so, also, we are to be shepherd kings 
of the creation, devoting ourselves to the service of both God and God's creation.

Given the responsibilities believers have to the creation, Devotional Biology ends most of its chapters with Christian responsibilities that arise from the study of that chapter. This includes topics like hunting and harvesting, gluttony and hoarding, pollution and global warming, recycling and landfills, land and water use and community development, animal research and animal care, curing and preventing disease, extinction and exotic introductions, antibiotics, insecticides and herbicides, mining, breeding, abortion, genetic engineering, cloning, birth control, IVF, and fertility drugs. These include priestly responsibilities of how to use the biology of that particular chapter to learn more about God's nature, and how to allow that increased knowledge of God to induce worship, and bring others into that worship. Devotional Biology also includes kingly responsibilities such as how to preserve and enhance creation's glorification of God. The reader of Devotional Biology learns how to use the creation to better know God, and learns how to better take care of and improve the creation that God has given us.

\section{THE TEXT'S IMPLEMENTATION}

KPW wrote Devotional Biology while employed at Truett McConnell University. In the Fall of 2012, BI 101, one of two biology courses at Truett McConnell for non-majors, was revised. Devotional Biology was adopted as the only required textbook for the course and the course name was changed to 'Concepts in Biology'. In the Fall of 2015, BI 101 was made the only required science course in the general education requirements at Truett McConnell. Consequently, since the Fall of 2015, every undergraduate student matriculating into Truett McConnell must take BI 101 where Devotional Biology is the only required text. BI 101 is offered in traditional classroom settings on campus, with different sections taught by three different Truett McConnell faculty (this paper's KPW, AJF, TH). BI 101 is also offered online, with video lectures by KPW. As an approved course for dual enrolment in Georgia, upper-level high school students also take BI 101-some taught by Truett McConnell faculty on the Truett McConnell campus, and others taught using KPW's video lectures in either online or high school settings. By ICC 2018, BI 101 will have been taught with this textbook by KPW for thirteen semesters (Fall 2011 through Spring 2018, less Fall 2017), by TH for ten semesters (Summer and Fall 2012, Fall 2013, Spring 2014 through Spring 2018), and by AF for four successive semesters (Fall 2016 through Spring 2018). By ICC 2018 something on the order of 850 Truett students and 450 Georgia dual enrollment students will have been taught using the Devotional Biology textbook.

At Bryan College, Devotional Biology became one of two required texts for 'Introduction to Biology' (BIO111) in the 2014/15 academic year. Beginning in the Fall of 2017, BIO111 was modified, renamed 'God's Revelation in Biology', and Devotional Biology became the only required text. By ICC 2018, BIO111 will have been taught with this textbook by SH for eight successive semesters (Fall 2014 through Spring 2018) and ND for one (Fall 2015). By ICC 2018 something on the order of 200 Bryan students will have been taught using the Devotional Biology textbook.
At The Master's University, Devotional Biology is the primary text for 'Essentials of Biology' (LS 150), the non-majors biology course required for all students. By ICC 2018 this paper's author, JF, will have taught LS 150 with this textbook for 6 successive semesters (Fall 2015 through Spring 2018). By ICC 2018, something on the order of 600 Master's University students and 40 California dual enrollment students will have been taught using this textbook.

In August of 2017, a home school course using the Devotional Biology textbook and a new set of KPW's video lectures were offered for sale by Compass Classroom. By the ICC 2018, several hundred high school students will probably have been taught using this textbook.

\section{THE TEXT'S EVALUATION}

In the 2013/2014 academic year, Truett McConnell faculty adopted a general education program with BI 101 as its only science course (and Devotional Biology as its only science textbook). At the end of the Fall semester of 2013, KPW included a question on the final (essay) exam in his sections of BI 101 that provided student evaluation of the course and its textbook. The students were asked "Imagine that you encounter an entering Truett student who is disgruntled about having to take BI 101 (because he or she doesn't like science and/or he or she 'can't do science'). Compose an essay that encourages such a student to see the advantages of taking BI 101." All the questions on the exam, including this one, were provided to students one week prior to the exam. KPW was expecting an answer that used the reasons Christians should study science as enumerated in chapter one of the Devotional Biology text. However, most students offered reasons of a different nature - many of which provided unexpected course evaluations and feedback. From that point forward, KPW offered the same question on the final exam for all sections of the course he taught. These student opinions are included in Table 1. The reader should be reminded while examining Table 1 that none of these particular answers were prompted, and almost none of them were expected. Thus, the expected number of student responses in most cases is zero. Receiving one or more positive responses on any given point is strong support of the text's success on that point.

In the spring of 2017, JF developed a set of student evaluation questions and had students in the 'Essentials of Biology' course (LS 150) at The Master's University fill out the questionnaire. The same questionnaire was given to students in the 'Concepts of Biology' course (BI 101) at Truett McConnell University in the fall of 2017 (sections taught by TH and AF) and the spring of 2018 (sections taught by TH, AJF, and KPW). Most of the same questions were given to students in the 'God's Revelation in Biology' course (BIO111) at Bryan College (taught by SH). The results of all these surveys are given in Table 2 . In contrast to Table 1 , students were prompted for answers, so here strong support of the text's success only comes with large percentages of the students scoring 'Agree' and 'Strongly Agree'.

\section{CONCLUSION}

Students at three different institutions (Truett McConnell University in Tables 1 and 2 and Bryan College and The Master's University in Table 2), under five different professors (KPW in Tables 1 and 2, AF \& JF \& KPW \& SH \& TH in Table 2), during ten different 
Table 1. Student opinions, Fall 2013 through Spring 2017 from KPW's sections of Truett McConnell College/University's 'Concepts in Biology' (BI 101) — a course developed around Devotional Biology. Note: None of these responses were prompted. These were reasons the students volunteered for why they thought the course/textbook was profitable for a student to take.

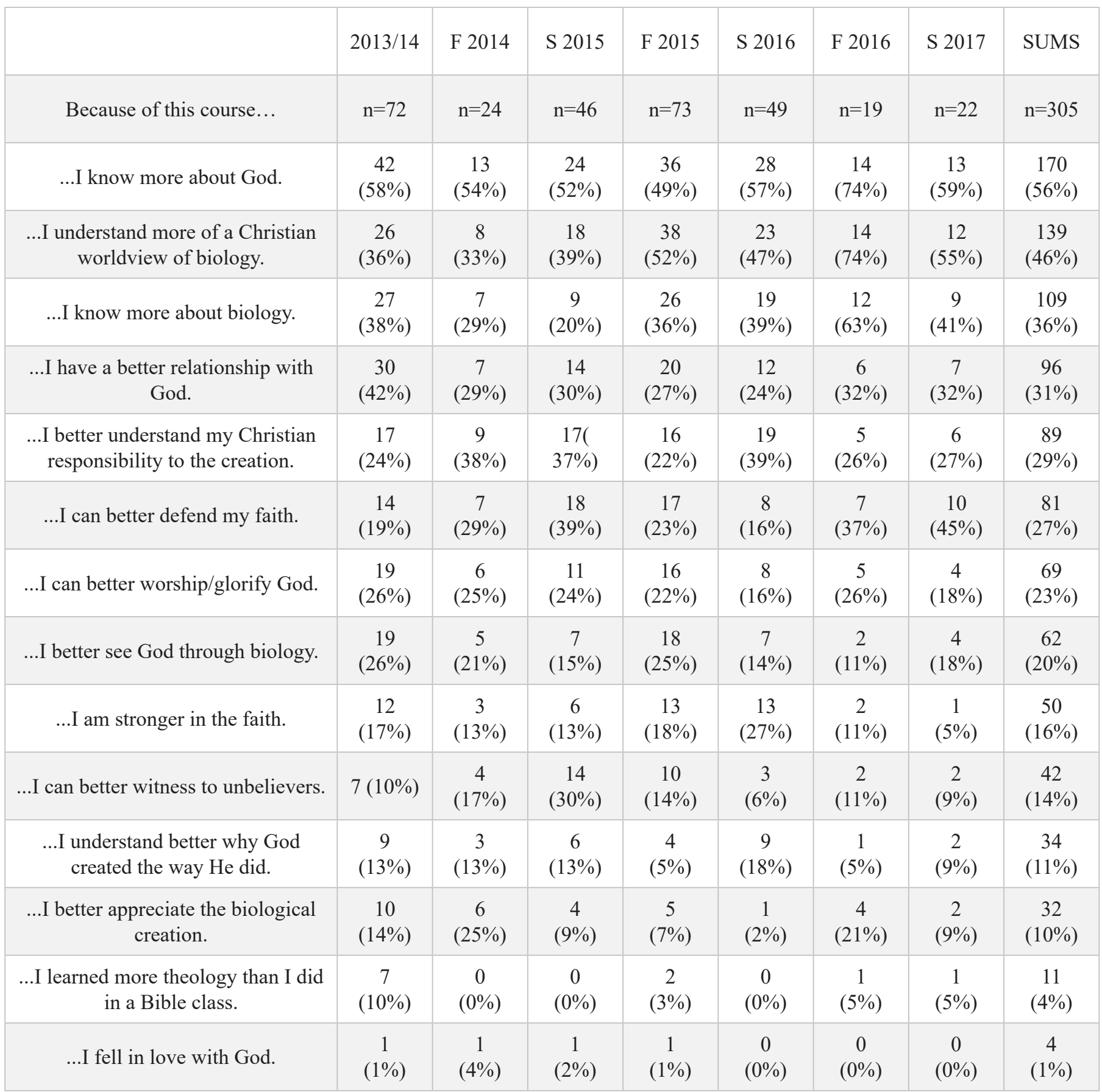


Table 2. Student Opinion Polls from Courses with Devotional Biology as their Primary Text: KEY TO OPINION POLL ANSWERS: A: Agree; D: Disagree; N: Neutral; SA: Strongly Agree; SD: Strongly Disagree. KEY TO SEMESTER: F17: fall semester 2017; S17: spring semester 2017; S18: spring semester 2018. Different professors teaching the course in the same semester are denoted by 'A', 'B', etc. with no particular order to preserve the anonymity of the professor and institution.

1. I liked science before I took this course.

\begin{tabular}{|c|c|c|c|c|c|c|c|c|c|c|c|}
\hline \multirow[b]{2}{*}{ S17 } & \multicolumn{2}{|c|}{ SD } & \multicolumn{2}{|c|}{ D } & \multicolumn{2}{|c|}{$\mathrm{N}$} & \multicolumn{2}{|c|}{ A } & \multicolumn{2}{|c|}{ SA } & $\mathrm{A}+\mathrm{SA}$ \\
\hline & 5 & $(7 \%)$ & 12 & $(17 \%)$ & 20 & $(29 \%)$ & 20 & $(29 \%)$ & 13 & $(19 \%)$ & $(47 \%)$ \\
\hline F17-A & 3 & $(6 \%)$ & 4 & $(9 \%)$ & 14 & $(30 \%)$ & 11 & $(23 \%)$ & 15 & $(32 \%)$ & $(55 \%)$ \\
\hline F17-B & 1 & $(3 \%)$ & 5 & $(14 \%)$ & 11 & $(31 \%)$ & 14 & $(40 \%)$ & 4 & $(11 \%)$ & $(51 \%)$ \\
\hline F17-C & 4 & $(5 \%)$ & 8 & $(9 \%)$ & 27 & $(32 \%)$ & 33 & $(39 \%)$ & 13 & $(15 \%)$ & $(54 \%)$ \\
\hline S18-A & 4 & $(9 \%)$ & 5 & $(11 \%)$ & 10 & $(23 \%)$ & 20 & $(45 \%)$ & 5 & $(11 \%)$ & $(57 \%)$ \\
\hline S18-B & 2 & $(5 \%)$ & 7 & $(18 \%)$ & 12 & $(30 \%)$ & 11 & $(28 \%)$ & 8 & $(20 \%)$ & $(48 \%)$ \\
\hline S18-C & 1 & $(6 \%)$ & 0 & $(0 \%)$ & 2 & $(12 \%)$ & 6 & $(35 \%)$ & 8 & $(47 \%)$ & $(82 \%)$ \\
\hline S18-D & 0 & $(0 \%)$ & 3 & $(17 \%)$ & 4 & $(22 \%)$ & 8 & $(44 \%)$ & 3 & $(17 \%)$ & $(61 \%)$ \\
\hline COTAL & 20 & $(6 \%)$ & 44 & $(12 \%)$ & \#\# & $(28 \%)$ & 123 & $(35 \%)$ & 69 & $(19 \%)$ & $(54 \%)$ \\
\hline
\end{tabular}

2. Through the Devotional Biology textbook I learned to like science.

\begin{tabular}{|c|c|c|c|c|c|c|c|c|c|c|c|}
\hline \multirow[b]{2}{*}{ S17 } & \multicolumn{2}{|c|}{ SD } & \multicolumn{2}{|c|}{$\mathrm{D}$} & \multicolumn{2}{|c|}{$\mathrm{N}$} & \multicolumn{2}{|c|}{ A } & \multicolumn{2}{|c|}{ SA } & \multirow{2}{*}{$\frac{\mathrm{A}+\mathrm{SA}}{(50 \%)}$} \\
\hline & 4 & $(6 \%)$ & 8 & $(11 \%)$ & 23 & $(33 \%)$ & 27 & $(39 \%)$ & 8 & $(11 \%)$ & \\
\hline F17-A & 2 & $(4 \%)$ & 5 & $(11 \%)$ & 13 & $(28 \%)$ & 19 & $(40 \%)$ & 8 & $(17 \%)$ & $(57 \%)$ \\
\hline F17-B & 2 & $(6 \%)$ & 3 & $(9 \%)$ & 18 & $(51 \%)$ & 12 & $(34 \%)$ & 0 & $(0 \%)$ & $(34 \%)$ \\
\hline F17-C & 3 & $(4 \%)$ & 6 & $(7 \%)$ & 28 & $(33 \%)$ & 31 & $(36 \%)$ & 17 & $(20 \%)$ & $(56 \%)$ \\
\hline S18-A & 2 & $(5 \%)$ & 6 & $(14 \%)$ & 14 & $(32 \%)$ & 18 & $(41 \%)$ & 4 & $(9 \%)$ & $(50 \%)$ \\
\hline S18-B & 0 & $(0 \%)$ & 2 & $(5 \%)$ & 13 & $(33 \%)$ & 15 & $(38 \%)$ & 10 & $(25 \%)$ & $(63 \%)$ \\
\hline $\mathrm{S} 18-\mathrm{C}$ & 0 & $(0 \%)$ & 0 & $(0 \%)$ & 4 & $(24 \%)$ & 8 & $(47 \%)$ & 5 & $(29 \%)$ & $(76 \%)$ \\
\hline S18-D & 0 & $(0 \%)$ & 1 & $(6 \%)$ & 7 & $(39 \%)$ & 9 & $(50 \%)$ & 1 & $(6 \%)$ & $(56 \%)$ \\
\hline TOTAL & 13 & $(4 \%)$ & 31 & $(9 \%)$ & \#\# & $(34 \%)$ & 139 & $(39 \%)$ & 53 & $(15 \%)$ & $(54 \%)$ \\
\hline
\end{tabular}

3. Through the Devotional Biology textbook I learned biology I didn't know before.

\begin{tabular}{|c|c|c|c|c|c|c|c|c|c|c|c|}
\hline \multirow[b]{2}{*}{ S17 } & \multicolumn{2}{|c|}{ SD } & \multicolumn{2}{|c|}{$\mathrm{D}$} & \multicolumn{2}{|c|}{$\mathrm{N}$} & \multicolumn{2}{|c|}{ A } & \multicolumn{2}{|c|}{ SA } & \multirow{2}{*}{$\frac{\mathrm{A}+\mathrm{SA}}{(80 \%)}$} \\
\hline & 2 & $(3 \%)$ & 3 & $(4 \%)$ & 9 & $(13 \%)$ & 25 & $(36 \%)$ & 31 & $(44 \%)$ & \\
\hline F17-A & 1 & $(2 \%)$ & 1 & $(2 \%)$ & 2 & $(4 \%)$ & 17 & $(36 \%)$ & 26 & $(55 \%)$ & $(91 \%)$ \\
\hline F17-B & 0 & $(0 \%)$ & 2 & $(6 \%)$ & 7 & $(20 \%)$ & 18 & $(51 \%)$ & 8 & $(23 \%)$ & $(74 \%)$ \\
\hline F17-C & 2 & $(2 \%)$ & 5 & $(6 \%)$ & 4 & $(5 \%)$ & 39 & $(46 \%)$ & 35 & $(41 \%)$ & $(87 \%)$ \\
\hline S18-A & 3 & $(7 \%)$ & 1 & $(2 \%)$ & 2 & $(5 \%)$ & 19 & $(44 \%)$ & 18 & $(42 \%)$ & $(86 \%)$ \\
\hline S18-B & 1 & $(3 \%)$ & 0 & $(0 \%)$ & 2 & $(5 \%)$ & 15 & $(38 \%)$ & 22 & $(55 \%)$ & $(93 \%)$ \\
\hline S18-C & 0 & $(0 \%)$ & 1 & $(6 \%)$ & 1 & $(6 \%)$ & 6 & $(35 \%)$ & 9 & $(53 \%)$ & $(88 \%)$ \\
\hline S18-D & 0 & $(0 \%)$ & 1 & $(6 \%)$ & 4 & $(22 \%)$ & 4 & $(22 \%)$ & 9 & $(50 \%)$ & $(72 \%)$ \\
\hline TOTAL & 9 & $(3 \%)$ & 14 & $(4 \%)$ & 31 & $(9 \%)$ & 143 & $(40 \%)$ & 158 & $(45 \%)$ & $(85 \%)$ \\
\hline
\end{tabular}


Table 2, continued.

4. Through the Devotional Biology textbook I gained a distinctively Christian perspective of biology I didn't have before.

\begin{tabular}{|c|c|c|c|c|c|c|c|c|c|c|c|}
\hline \multirow[b]{2}{*}{ S17 } & \multicolumn{2}{|c|}{ SD } & \multicolumn{2}{|c|}{$\mathrm{D}$} & \multicolumn{2}{|c|}{$\mathrm{N}$} & \multicolumn{2}{|c|}{ A } & \multicolumn{2}{|c|}{ SA } & \multirow{2}{*}{$\begin{array}{l}\mathrm{A}+\mathrm{SA} \\
(76 \%)\end{array}$} \\
\hline & 0 & $(0 \%)$ & 6 & $(9 \%)$ & 11 & $(16 \%)$ & 20 & $(29 \%)$ & 33 & $(47 \%)$ & \\
\hline F17-A & 1 & $(2 \%)$ & 1 & $(2 \%)$ & 0 & $(0 \%)$ & 13 & $(28 \%)$ & 32 & $(68 \%)$ & $(96 \%)$ \\
\hline F17-B & 0 & $(0 \%)$ & 1 & $(3 \%)$ & 5 & $(14 \%)$ & 13 & $(37 \%)$ & 16 & $(46 \%)$ & $(83 \%)$ \\
\hline F17-C & 1 & $(1 \%)$ & 5 & $(6 \%)$ & 13 & $(15 \%)$ & 35 & $(41 \%)$ & 31 & $(36 \%)$ & $(78 \%)$ \\
\hline S18-A & 0 & $(0 \%)$ & 3 & $(7 \%)$ & 6 & $(14 \%)$ & 19 & $(43 \%)$ & 16 & $(36 \%)$ & $(80 \%)$ \\
\hline S18-B & 1 & $(3 \%)$ & 0 & $(0 \%)$ & 2 & $(5 \%)$ & 7 & $(18 \%)$ & 30 & $(75 \%)$ & $(93 \%)$ \\
\hline S18-C & 0 & $(0 \%)$ & 1 & $(6 \%)$ & 3 & $(18 \%)$ & 5 & $(29 \%)$ & 8 & $(47 \%)$ & $(76 \%)$ \\
\hline S18-D & 0 & $(0 \%)$ & 0 & $(0 \%)$ & 3 & $(17 \%)$ & 7 & $(39 \%)$ & 8 & $(44 \%)$ & $(83 \%)$ \\
\hline S18-E & 0 & $(0 \%)$ & 1 & $(6 \%)$ & 1 & $(6 \%)$ & 11 & $(65 \%)$ & 4 & $(24 \%)$ & (88\%) \\
\hline TOTAL & 3 & $(1 \%)$ & 17 & $(5 \%)$ & 43 & $(12 \%)$ & 119 & $(33 \%)$ & 174 & $(49 \%)$ & $(82 \%)$ \\
\hline
\end{tabular}

5. Through the Devotional Biology textbook I learned new things about God.

\begin{tabular}{|c|c|c|c|c|c|c|c|c|c|c|c|}
\hline \multirow[b]{2}{*}{ S17 } & \multicolumn{2}{|c|}{ SD } & \multicolumn{2}{|c|}{$\mathrm{D}$} & \multicolumn{2}{|c|}{$\mathrm{N}$} & \multicolumn{2}{|c|}{ A } & \multicolumn{2}{|c|}{ SA } & \multirow{2}{*}{$\begin{array}{l}\mathrm{A}+\mathrm{SA} \\
(79 \%)\end{array}$} \\
\hline & 1 & $(1 \%)$ & 5 & $(7 \%)$ & 9 & $(13 \%)$ & 28 & $(40 \%)$ & 27 & $(39 \%)$ & \\
\hline F17-A & 1 & $(2 \%)$ & 0 & $(0 \%)$ & 3 & $(6 \%)$ & 15 & $(32 \%)$ & 28 & $(60 \%)$ & $(91 \%)$ \\
\hline F17-B & 0 & $(0 \%)$ & 1 & $(3 \%)$ & 6 & $(17 \%)$ & 16 & $(46 \%)$ & 12 & $(34 \%)$ & $(80 \%)$ \\
\hline F17-C & 0 & $(0 \%)$ & 6 & $(7 \%)$ & 11 & $(13 \%)$ & 36 & $(42 \%)$ & 32 & $(38 \%)$ & $(80 \%)$ \\
\hline S18-A & 0 & $(0 \%)$ & 5 & $(11 \%)$ & 5 & $(11 \%)$ & 23 & $(52 \%)$ & 11 & $(25 \%)$ & $(77 \%)$ \\
\hline S18-B & 0 & $(0 \%)$ & 0 & $(0 \%)$ & 0 & $(0 \%)$ & 13 & $(33 \%)$ & 27 & $(68 \%)$ & $(100 \%)$ \\
\hline S18-C & 0 & $(0 \%)$ & 0 & $(0 \%)$ & 0 & $(0 \%)$ & 7 & $(41 \%)$ & 10 & $(59 \%)$ & $(100 \%)$ \\
\hline S18-D & 0 & $(0 \%)$ & 0 & $(0 \%)$ & 0 & $(0 \%)$ & 8 & $(44 \%)$ & 10 & $(56 \%)$ & $(100 \%)$ \\
\hline S18-E & 0 & $(0 \%)$ & 1 & $(6 \%)$ & 2 & $(12 \%)$ & 7 & $(41 \%)$ & 7 & $(41 \%)$ & $(82 \%)$ \\
\hline TOTAL & 2 & $(1 \%)$ & 17 & $(5 \%)$ & 34 & $(10 \%)$ & 146 & $(41 \%)$ & 157 & $(44 \%)$ & $(85 \%)$ \\
\hline
\end{tabular}

6. Through the Devotional Biology textbook I learned to recognize God in the creation in ways I didn't before.

\begin{tabular}{|c|c|c|c|c|c|c|c|c|c|c|c|}
\hline \multirow[b]{2}{*}{ S17 } & \multicolumn{2}{|c|}{ SD } & \multicolumn{2}{|c|}{$\mathrm{D}$} & \multicolumn{2}{|c|}{$\mathrm{N}$} & \multicolumn{2}{|c|}{ A } & \multicolumn{2}{|c|}{ SA } & \multirow{2}{*}{$\frac{A+S A}{(80 \%)}$} \\
\hline & 2 & $(3 \%)$ & 3 & $(4 \%)$ & 9 & $(13 \%)$ & 21 & $(30 \%)$ & 35 & $(50 \%)$ & \\
\hline F17-A & 1 & $(2 \%)$ & 0 & $(0 \%)$ & 1 & $(2 \%)$ & 12 & $(26 \%)$ & 33 & $(70 \%)$ & $(96 \%)$ \\
\hline F17-B & 0 & $(0 \%)$ & 0 & $(0 \%)$ & 2 & $(6 \%)$ & 28 & $(80 \%)$ & 5 & $(14 \%)$ & $(94 \%)$ \\
\hline F17-C & 0 & $(0 \%)$ & 0 & $(0 \%)$ & 8 & $(9 \%)$ & 39 & $(46 \%)$ & 38 & $(45 \%)$ & $(91 \%)$ \\
\hline S18-A & 0 & $(0 \%)$ & 3 & $(7 \%)$ & 3 & $(7 \%)$ & 15 & $(36 \%)$ & 21 & $(50 \%)$ & $(86 \%)$ \\
\hline S18-B & 0 & $(0 \%)$ & 0 & $(0 \%)$ & 1 & $(3 \%)$ & 7 & $(18 \%)$ & 32 & $(80 \%)$ & $(98 \%)$ \\
\hline S18-C & 0 & $(0 \%)$ & 0 & $(0 \%)$ & 2 & $(12 \%)$ & 6 & $(35 \%)$ & 9 & $(53 \%)$ & $\begin{array}{l}(88 \%) \\
\end{array}$ \\
\hline S18-D & 0 & $(0 \%)$ & 0 & $(0 \%)$ & 1 & $(6 \%)$ & 8 & $(44 \%)$ & 9 & $(50 \%)$ & $\begin{array}{l}(94 \%) \\
\end{array}$ \\
\hline S18-E & 0 & $(0 \%)$ & 3 & $(18 \%)$ & 5 & $(29 \%)$ & 4 & $(24 \%)$ & 5 & $(29 \%)$ & $(53 \%)$ \\
\hline TOTAL & 3 & $(1 \%)$ & 6 & $(2 \%)$ & 27 & $(8 \%)$ & 136 & $(38 \%)$ & 182 & $(51 \%)$ & $(90 \%)$ \\
\hline
\end{tabular}


Wise et al. $\triangleleft$ Devotional Biology 2018 ICC

Table 2, continued.

7. Through the Devotional Biology textbook I learned about responsibilities that I didn't know I had before.

\begin{tabular}{|c|c|c|c|c|c|c|c|c|c|c|c|}
\hline \multirow[b]{2}{*}{ S17 } & \multicolumn{2}{|c|}{ SD } & \multicolumn{2}{|c|}{$\mathrm{D}$} & \multicolumn{2}{|c|}{$\mathrm{N}$} & \multicolumn{2}{|c|}{ A } & \multicolumn{2}{|c|}{ SA } & \multirow{2}{*}{$\frac{A+S A}{(73 \%)}$} \\
\hline & 1 & $(1 \%)$ & 3 & $(4 \%)$ & 15 & $(21 \%)$ & 34 & $(49 \%)$ & 17 & $(24 \%)$ & \\
\hline F17-A & 1 & $(2 \%)$ & 2 & $(4 \%)$ & 6 & $(13 \%)$ & 19 & $(40 \%)$ & 19 & $(40 \%)$ & (81\%) \\
\hline F17-B & 0 & $(0 \%)$ & 3 & $(9 \%)$ & 11 & $(31 \%)$ & 18 & $(51 \%)$ & 3 & $(9 \%)$ & $(60 \%)$ \\
\hline F17-C & 1 & $(1 \%)$ & 6 & $(7 \%)$ & 13 & $(15 \%)$ & 45 & $(53 \%)$ & 20 & $(24 \%)$ & $(76 \%)$ \\
\hline S18-A & 0 & $(0 \%)$ & 6 & $(14 \%)$ & 4 & $(9 \%)$ & 25 & $(58 \%)$ & 8 & $(19 \%)$ & $(77 \%)$ \\
\hline S18-B & 0 & $(0 \%)$ & 0 & $(0 \%)$ & 4 & $(10 \%)$ & 14 & $(35 \%)$ & 22 & $(55 \%)$ & $(90 \%)$ \\
\hline S18-C & 0 & $(0 \%)$ & 1 & $(6 \%)$ & 4 & $(24 \%)$ & 6 & $(35 \%)$ & 6 & $(35 \%)$ & $(71 \%)$ \\
\hline S18-D & 0 & $(0 \%)$ & 0 & $(0 \%)$ & 1 & $(6 \%)$ & 9 & $(50 \%)$ & 8 & $(44 \%)$ & $(94 \%)$ \\
\hline S18-E & 0 & $(0 \%)$ & 3 & $(18 \%)$ & 4 & $(24 \%)$ & 6 & $(35 \%)$ & 4 & $(24 \%)$ & $(59 \%)$ \\
\hline TOTAL & 3 & $(1 \%)$ & 21 & $(6 \%)$ & 58 & $(16 \%)$ & 170 & $(48 \%)$ & 103 & $(29 \%)$ & $(77 \%)$ \\
\hline
\end{tabular}

8. Through the Devotional Biology textbook I learned new things about myself and my purpose.

\begin{tabular}{|c|cc|cc|cc|cc|cc|c|}
\cline { 2 - 12 } & \multicolumn{2}{|c|}{ SD } & \multicolumn{2}{|c|}{$\mathrm{D}$} & \multicolumn{3}{|c|}{$\mathrm{N}$} & \multicolumn{3}{|c|}{$\mathrm{A}$} & \multicolumn{3}{|c|}{ SA } & A+SA \\
\cline { 2 - 13 } S17 & 2 & $(3 \%)$ & 9 & $(13 \%)$ & 19 & $(28 \%)$ & 25 & $(37 \%)$ & 13 & $(19 \%)$ & $(56 \%)$ \\
\cline { 2 - 13 } F17-A & 1 & $(2 \%)$ & 2 & $(4 \%)$ & 6 & $(13 \%)$ & 21 & $(45 \%)$ & 17 & $(36 \%)$ & $(81 \%)$ \\
F17-B & 0 & $(0 \%)$ & 2 & $(6 \%)$ & 15 & $(43 \%)$ & 17 & $(49 \%)$ & 1 & $(3 \%)$ & $(51 \%)$ \\
F17-C & 2 & $(2 \%)$ & 4 & $(5 \%)$ & 22 & $(26 \%)$ & 37 & $(44 \%)$ & 19 & $(23 \%)$ & $(67 \%)$ \\
S18-A & 0 & $(0 \%)$ & 5 & $(12 \%)$ & 6 & $(14 \%)$ & 25 & $(58 \%)$ & 7 & $(16 \%)$ & $(74 \%)$ \\
S18-B & 1 & $(3 \%)$ & 1 & $(3 \%)$ & 4 & $(10 \%)$ & 25 & $(63 \%)$ & 9 & $(23 \%)$ & $(85 \%)$ \\
S18-C & 0 & $(0 \%)$ & 1 & $(6 \%)$ & 5 & $(29 \%)$ & 7 & $(41 \%)$ & 4 & $(24 \%)$ & $(65 \%)$ \\
S18-D & 0 & $(0 \%)$ & 0 & $(0 \%)$ & 4 & $(22 \%)$ & 11 & $(61 \%)$ & 3 & $(17 \%)$ & $(78 \%)$ \\
S18-E & 0 & $(0 \%)$ & 6 & $(35 \%)$ & 3 & $(18 \%)$ & 4 & $(24 \%)$ & 4 & $(24 \%)$ & $(47 \%)$ \\
\cline { 2 - 12 } TOTAL & 6 & $(2 \%)$ & 24 & $(7 \%)$ & 81 & $(23 \%)$ & 168 & $(48 \%)$ & 73 & $(21 \%)$ & $(68 \%)$ \\
\hline
\end{tabular}

9. Through the Devotional Biology textbook I learned to appreciate the creation in ways I didn't before.

\begin{tabular}{|c|c|c|c|c|c|c|c|c|c|c|c|}
\hline \multirow[b]{2}{*}{$\mathrm{S} 17$} & \multicolumn{2}{|c|}{ SD } & \multicolumn{2}{|c|}{$\mathrm{D}$} & \multicolumn{2}{|c|}{$\mathrm{N}$} & \multicolumn{2}{|c|}{ A } & \multicolumn{2}{|c|}{ SA } & \multirow{2}{*}{$\begin{array}{l}\mathrm{A}+\mathrm{SA} \\
(81 \%)\end{array}$} \\
\hline & 2 & $(3 \%)$ & 1 & $(1 \%)$ & 10 & $(14 \%)$ & 27 & $(39 \%)$ & 30 & $(43 \%)$ & \\
\hline F17-A & 1 & $(2 \%)$ & 0 & $(0 \%)$ & 1 & $(2 \%)$ & 16 & $(34 \%)$ & 29 & $(62 \%)$ & $(96 \%)$ \\
\hline F17-B & 0 & $(0 \%)$ & 0 & $(0 \%)$ & 2 & $17 \%$ & 28 & $(80 \%)$ & 5 & $(14 \%)$ & $(94 \%)$ \\
\hline F17-C & 0 & $(0 \%)$ & 2 & $(2 \%)$ & 2 & $(2 \%)$ & 39 & $(46 \%)$ & 41 & $(49 \%)$ & $(95 \%)$ \\
\hline S18-A & 0 & $(0 \%)$ & 4 & $(9 \%)$ & 2 & $(5 \%)$ & 14 & $(33 \%)$ & 23 & $(53 \%)$ & $(86 \%)$ \\
\hline S18-B & 0 & $(0 \%)$ & 0 & $(0 \%)$ & 1 & $(3 \%)$ & 10 & $(25 \%)$ & 29 & $(73 \%)$ & $(98 \%)$ \\
\hline S18-C & 0 & $(0 \%)$ & 0 & $(0 \%)$ & 1 & $(6 \%)$ & 8 & $(47 \%)$ & 8 & $(47 \%)$ & $(94 \%)$ \\
\hline S18-D & 0 & $(0 \%)$ & 0 & $(0 \%)$ & 1 & $(6 \%)$ & 10 & $(56 \%)$ & 7 & $(39 \%)$ & $\begin{array}{l}(94 \%) \\
\end{array}$ \\
\hline S18-E & 0 & $(0 \%)$ & 1 & $(6 \%)$ & 1 & $(6 \%)$ & 8 & $(47 \%)$ & 7 & $(41 \%)$ & $(88 \%)$ \\
\hline TOTAL & 3 & $(1 \%)$ & 7 & $(2 \%)$ & 20 & $(6 \%)$ & 152 & $(43 \%)$ & 172 & $(49 \%)$ & $(92 \%)$ \\
\hline
\end{tabular}


Table 2, continued.

10. Through the Devotional Biology textbook I learned new ways to use the creation to worship God.

\begin{tabular}{|c|c|c|c|c|c|c|c|c|c|c|c|}
\hline \multirow[b]{2}{*}{ S17 } & \multicolumn{2}{|c|}{ SD } & \multicolumn{2}{|c|}{$\mathrm{D}$} & \multicolumn{2}{|c|}{$\mathrm{N}$} & \multicolumn{2}{|c|}{ A } & \multicolumn{2}{|c|}{ SA } & \multirow{2}{*}{$\begin{array}{l}\mathrm{A}+\mathrm{SA} \\
(74 \%)\end{array}$} \\
\hline & 1 & $(1 \%)$ & 2 & $(3 \%)$ & 15 & $(22 \%)$ & 30 & $(43 \%)$ & 21 & $(30 \%)$ & \\
\hline F17-A & 1 & $(2 \%)$ & 1 & $(2 \%)$ & 3 & $(6 \%)$ & 17 & $(36 \%)$ & 25 & $(53 \%)$ & $(89 \%)$ \\
\hline F17-B & 0 & $(0 \%)$ & 0 & $(0 \%)$ & 6 & $(17 \%)$ & 19 & $(54 \%)$ & 10 & $(29 \%)$ & $(83 \%)$ \\
\hline F17-C & 1 & $(1 \%)$ & 0 & $(0 \%)$ & 13 & $(15 \%)$ & 42 & $(49 \%)$ & 29 & $(34 \%)$ & $(84 \%)$ \\
\hline S18-A & 0 & $(0 \%)$ & 3 & $(7 \%)$ & 6 & $(14 \%)$ & 24 & $(56 \%)$ & 10 & $(23 \%)$ & $(79 \%)$ \\
\hline S18-B & 0 & $(0 \%)$ & 1 & $(3 \%)$ & 0 & $(0 \%)$ & 12 & $(30 \%)$ & 27 & $(68 \%)$ & $(98 \%)$ \\
\hline S18-C & 0 & $(0 \%)$ & 1 & $(6 \%)$ & 1 & $(6 \%)$ & 10 & $(59 \%)$ & 5 & $(29 \%)$ & $(88 \%)$ \\
\hline S18-D & 0 & $(0 \%)$ & 0 & $(0 \%)$ & 0 & $(0 \%)$ & 10 & $(56 \%)$ & 8 & $(44 \%)$ & $(100 \%)$ \\
\hline S18-E & 2 & $(13 \%)$ & 3 & $(19 \%)$ & 2 & $(13 \%)$ & 6 & $(38 \%)$ & 3 & $(19 \%)$ & $(56 \%)$ \\
\hline TOTAL & 3 & $(1 \%)$ & 8 & $(2 \%)$ & 44 & $(12 \%)$ & 164 & $(46 \%)$ & 135 & $(38 \%)$ & $(84 \%)$ \\
\hline
\end{tabular}

11. Through the Devotional Biology textbook I can defend my faith more effectively.

\begin{tabular}{|c|c|c|c|c|c|c|c|c|c|c|c|}
\hline \multirow[b]{2}{*}{ S17 } & \multicolumn{2}{|c|}{ SD } & \multicolumn{2}{|c|}{ D } & \multicolumn{2}{|c|}{$\mathrm{N}$} & \multicolumn{2}{|c|}{ A } & \multicolumn{2}{|c|}{ SA } & $\mathrm{A}+\mathrm{SA}$ \\
\hline & 1 & $(1 \%)$ & 4 & $(6 \%)$ & 14 & $(20 \%)$ & 40 & $(57 \%)$ & 11 & $(16 \%)$ & $(73 \%)$ \\
\hline F17-A & 1 & $(2 \%)$ & 0 & $(0 \%)$ & 4 & $(9 \%)$ & 22 & $(48 \%)$ & 19 & $(41 \%)$ & $(89 \%)$ \\
\hline F17-B & 0 & $(0 \%)$ & 1 & $(3 \%)$ & 8 & $(23 \%)$ & 21 & $(60 \%)$ & 5 & $(14 \%)$ & $(74 \%)$ \\
\hline F17-C & 0 & $(0 \%)$ & 4 & $(5 \%)$ & 22 & $(26 \%)$ & 45 & $(54 \%)$ & 13 & $(15 \%)$ & $(69 \%)$ \\
\hline S18-A & 0 & $(0 \%)$ & 1 & $(2 \%)$ & 17 & $(40 \%)$ & 18 & $(42 \%)$ & 7 & $(16 \%)$ & $(58 \%)$ \\
\hline S18-B & 1 & $(3 \%)$ & 0 & $(0 \%)$ & 4 & $(10 \%)$ & 13 & $(33 \%)$ & 22 & $(55 \%)$ & $(88 \%)$ \\
\hline S18-C & 0 & $(0 \%)$ & 0 & $(0 \%)$ & 1 & $(6 \%)$ & 7 & $(41 \%)$ & 9 & $(53 \%)$ & $\begin{array}{l}(94 \%) \\
\end{array}$ \\
\hline S18-D & 0 & $(0 \%)$ & 0 & $(0 \%)$ & 2 & $(11 \%)$ & 12 & $(67 \%)$ & 4 & $(22 \%)$ & $(89 \%)$ \\
\hline S18-E & 2 & $(12 \%)$ & 1 & $(6 \%)$ & 6 & $(35 \%)$ & 3 & $(18 \%)$ & 5 & $(29 \%)$ & $(47 \%)$ \\
\hline TOTAL & 3 & $(1 \%)$ & 10 & $(3 \%)$ & 72 & $(20 \%)$ & 178 & $(50 \%)$ & 90 & $(25 \%)$ & $(76 \%)$ \\
\hline
\end{tabular}

12. Through the Devotional Biology textbook I can better use the creation to lead others to Christ.

\begin{tabular}{|c|c|c|c|c|c|c|c|c|c|c|c|}
\hline \multirow[b]{2}{*}{ S17 } & \multicolumn{2}{|c|}{ SD } & \multicolumn{2}{|c|}{$\mathrm{D}$} & \multicolumn{2}{|c|}{$\mathrm{N}$} & \multicolumn{2}{|c|}{ A } & \multicolumn{2}{|c|}{ SA } & \multirow{2}{*}{$\frac{\mathrm{A}+\mathrm{SA}}{(77 \%)}$} \\
\hline & 2 & $(3 \%)$ & 4 & $(6 \%)$ & 10 & $(14 \%)$ & 30 & $(43 \%)$ & 24 & $(34 \%)$ & \\
\hline F17-A & 1 & $(2 \%)$ & 1 & $(2 \%)$ & 1 & $(2 \%)$ & 18 & $(39 \%)$ & 25 & $(54 \%)$ & $(93 \%)$ \\
\hline F17-B & 0 & $(0 \%)$ & 1 & $(3 \%)$ & 5 & $(14 \%)$ & 23 & $(66 \%)$ & 6 & $(17 \%)$ & $(83 \%)$ \\
\hline F17-C & 0 & $(0 \%)$ & 2 & $(2 \%)$ & 19 & $(23 \%)$ & 41 & $(49 \%)$ & 22 & $(26 \%)$ & $(75 \%)$ \\
\hline S18-A & 0 & $(0 \%)$ & 2 & $(5 \%)$ & 9 & $(21 \%)$ & 23 & $(53 \%)$ & 9 & $(21 \%)$ & $(74 \%)$ \\
\hline S18-B & 1 & $(3 \%)$ & 1 & $(3 \%)$ & 3 & $(8 \%)$ & 12 & $(30 \%)$ & 23 & $(58 \%)$ & $(88 \%)$ \\
\hline S18-C & 0 & $(0 \%)$ & 0 & $(0 \%)$ & 0 & $(0 \%)$ & 8 & $(47 \%)$ & 9 & $(53 \%)$ & $(100 \%)$ \\
\hline S18-D & 0 & $(0 \%)$ & 0 & $(0 \%)$ & 3 & $(17 \%)$ & 7 & $(39 \%)$ & 8 & $(44 \%)$ & $(83 \%)$ \\
\hline S18-E & 1 & $(6 \%)$ & 4 & $(25 \%)$ & 2 & $(13 \%)$ & 6 & $(38 \%)$ & 3 & $(19 \%)$ & $(56 \%)$ \\
\hline TOTAL & 4 & $(1 \%)$ & 11 & $(3 \%)$ & 50 & $(14 \%)$ & 162 & $(46 \%)$ & 126 & $(36 \%)$ & $(82 \%)$ \\
\hline
\end{tabular}


Table 2, continued.

13. Through the Devotional Biology textbook my faith was strengthened.

\begin{tabular}{|c|c|c|c|c|c|c|c|c|c|c|c|}
\hline \multirow[b]{2}{*}{ S17 } & \multicolumn{2}{|c|}{ SD } & \multicolumn{2}{|c|}{ D } & \multicolumn{2}{|c|}{$\mathrm{N}$} & \multicolumn{2}{|c|}{ A } & \multicolumn{2}{|c|}{ SA } & \multirow{2}{*}{$\frac{A+S A}{(75 \%)}$} \\
\hline & 2 & $(3 \%)$ & 2 & $(3 \%)$ & 13 & $(19 \%)$ & 30 & $(43 \%)$ & 22 & $(32 \%)$ & \\
\hline F17-A & 1 & $(2 \%)$ & 1 & $(2 \%)$ & 3 & $(7 \%)$ & 18 & $(39 \%)$ & 23 & $(50 \%)$ & $(89 \%)$ \\
\hline F17-B & 0 & $(0 \%)$ & 2 & $(6 \%)$ & 8 & $(23 \%)$ & 20 & $(57 \%)$ & 5 & $(14 \%)$ & $(71 \%)$ \\
\hline F17-C & 1 & $(1 \%)$ & 4 & $(5 \%)$ & 17 & $(20 \%)$ & 37 & $(44 \%)$ & 26 & $(31 \%)$ & $(74 \%)$ \\
\hline S18-A & 1 & $(2 \%)$ & 1 & $(2 \%)$ & 8 & $(19 \%)$ & 28 & $(65 \%)$ & 5 & $(12 \%)$ & $(77 \%)$ \\
\hline S18-B & 0 & $(0 \%)$ & 1 & $(3 \%)$ & 4 & $(10 \%)$ & 11 & $(28 \%)$ & 24 & $(60 \%)$ & $(88 \%)$ \\
\hline S18-C & 0 & $(0 \%)$ & 0 & $(0 \%)$ & 1 & $(6 \%)$ & 9 & $(53 \%)$ & 7 & $(41 \%)$ & $(94 \%)$ \\
\hline S18-D & 0 & $(0 \%)$ & 0 & $(0 \%)$ & 2 & $(11 \%)$ & 10 & $(56 \%)$ & 6 & $(33 \%)$ & $(89 \%)$ \\
\hline S18-E & 0 & $(0 \%)$ & 2 & $(13 \%)$ & 4 & $(25 \%)$ & 7 & $(44 \%)$ & 3 & $(19 \%)$ & $(63 \%)$ \\
\hline TOTAL & 5 & $(1 \%)$ & 11 & $(3 \%)$ & 56 & $(16 \%)$ & 163 & $(46 \%)$ & 118 & $(33 \%)$ & $(80 \%)$ \\
\hline
\end{tabular}

14. Through the Devotional Biology textbook my relationship with God improved.

\begin{tabular}{|c|c|c|c|c|c|c|c|c|c|c|c|}
\hline \multirow[b]{2}{*}{ S17 } & \multicolumn{2}{|c|}{ SD } & \multicolumn{2}{|c|}{$\mathrm{D}$} & \multicolumn{2}{|c|}{$\mathrm{N}$} & \multicolumn{2}{|c|}{ A } & \multicolumn{2}{|c|}{ SA } & \multirow{2}{*}{$\frac{\mathrm{A}+\mathrm{SA}}{(67 \%)}$} \\
\hline & 2 & $(3 \%)$ & 5 & $(7 \%)$ & 15 & $(22 \%)$ & 31 & $(46 \%)$ & 14 & $(21 \%)$ & \\
\hline F17-A & 1 & $(2 \%)$ & 0 & $(0 \%)$ & 6 & $(13 \%)$ & 20 & $(43 \%)$ & 19 & $(41 \%)$ & $(85 \%)$ \\
\hline F17-B & 0 & $(0 \%)$ & 2 & $(6 \%)$ & 8 & $(23 \%)$ & 22 & $(63 \%)$ & 3 & $(9 \%)$ & $(71 \%)$ \\
\hline F17-C & 1 & $(1 \%)$ & 4 & $(5 \%)$ & 29 & $(34 \%)$ & 35 & $(41 \%)$ & 16 & $(19 \%)$ & $(60 \%)$ \\
\hline S18-A & 1 & $(2 \%)$ & 3 & $(7 \%)$ & 12 & $(28 \%)$ & 21 & $(49 \%)$ & 6 & $(14 \%)$ & $(63 \%)$ \\
\hline S18-B & 0 & $(0 \%)$ & 1 & $(3 \%)$ & 4 & $(10 \%)$ & 12 & $(30 \%)$ & 23 & $(58 \%)$ & $(88 \%)$ \\
\hline S18-C & 0 & $(0 \%)$ & 0 & $(0 \%)$ & 2 & $(12 \%)$ & 11 & $(65 \%)$ & 4 & $(24 \%)$ & $(88 \%)$ \\
\hline S18-D & 0 & $(0 \%)$ & 0 & $(0 \%)$ & 3 & $(17 \%)$ & 8 & $(44 \%)$ & 7 & $(39 \%)$ & $(83 \%)$ \\
\hline S18-E & 2 & $(13 \%)$ & 3 & $(19 \%)$ & 5 & $(31 \%)$ & 5 & $(31 \%)$ & 1 & $(6 \%)$ & $(38 \%)$ \\
\hline TOTAL & 5 & $(1 \%)$ & 15 & $(4 \%)$ & 79 & $(23 \%)$ & 160 & $(46 \%)$ & 92 & $(26 \%)$ & $(72 \%)$ \\
\hline
\end{tabular}

15. Through the Devotional Biology textbook I can better rule over the creation.

\begin{tabular}{|c|c|c|c|c|c|c|c|c|c|c|c|}
\hline \multirow[b]{2}{*}{ S17 } & \multicolumn{2}{|c|}{ SD } & \multicolumn{2}{|c|}{ D } & \multicolumn{2}{|c|}{$\mathrm{N}$} & \multicolumn{2}{|c|}{ A } & \multicolumn{2}{|c|}{ SA } & \multirow{2}{*}{$\frac{\mathrm{A}+\mathrm{SA}}{(69 \%)}$} \\
\hline & 2 & $(3 \%)$ & 3 & $(4 \%)$ & 17 & $(24 \%)$ & 32 & $(46 \%)$ & 16 & $(23 \%)$ & \\
\hline F17-A & 1 & $(2 \%)$ & 1 & $(2 \%)$ & 7 & $(15 \%)$ & 22 & $(48 \%)$ & 15 & $(33 \%)$ & $(80 \%)$ \\
\hline F17-B & 0 & $(0 \%)$ & 2 & $(6 \%)$ & 12 & $(34 \%)$ & 16 & $(46 \%)$ & 5 & $(14 \%)$ & $(60 \%)$ \\
\hline F17-C & 0 & $(0 \%)$ & 3 & $(4 \%)$ & 23 & $(27 \%)$ & 43 & $(51 \%)$ & 15 & $(18 \%)$ & $(69 \%)$ \\
\hline S18-A & 0 & $(0 \%)$ & 4 & $(9 \%)$ & 13 & $(30 \%)$ & 22 & $(51 \%)$ & 4 & $(9 \%)$ & $(60 \%)$ \\
\hline S18-B & 1 & $(3 \%)$ & 1 & $(3 \%)$ & 3 & $(8 \%)$ & 19 & $(48 \%)$ & 16 & $(40 \%)$ & $(88 \%)$ \\
\hline S18-C & 0 & $(0 \%)$ & 0 & $(0 \%)$ & 3 & $(18 \%)$ & 11 & $(65 \%)$ & 3 & $(18 \%)$ & $(82 \%)$ \\
\hline S18-D & 0 & $(0 \%)$ & 0 & $(0 \%)$ & 3 & $(17 \%)$ & 10 & $(56 \%)$ & 5 & $(28 \%)$ & $(83 \%)$ \\
\hline S18-E & 0 & $(0 \%)$ & 5 & $(29 \%)$ & 4 & $(24 \%)$ & 6 & $(35 \%)$ & 2 & $(12 \%)$ & $(47 \%)$ \\
\hline TOTAL & 4 & $(1 \%)$ & 14 & $(4 \%)$ & 81 & $(23 \%)$ & 175 & $(50 \%)$ & 79 & $(22 \%)$ & $(72 \%)$ \\
\hline
\end{tabular}


Table 2, continued.

16. Through the Devotional Biology textbook I can make better ethical decisions.

\begin{tabular}{|c|cc|cc|cc|cc|cc|c|}
\cline { 2 - 12 } & \multicolumn{2}{|c|}{ SD } & \multicolumn{2}{|c|}{$\mathrm{D}$} & \multicolumn{2}{|c|}{$\mathrm{N}$} & \multicolumn{3}{|c|}{$\mathrm{A}$} & \multicolumn{3}{|c|}{ SA } & A+SA \\
\cline { 2 - 13 } S17 & 2 & $(3 \%)$ & 4 & $(6 \%)$ & 9 & $(13 \%)$ & 33 & $(47 \%)$ & 22 & $(31 \%)$ & $(79 \%)$ \\
\cline { 2 - 13 } F17-A & 1 & $(2 \%)$ & 0 & $(0 \%)$ & 5 & $(11 \%)$ & 23 & $(50 \%)$ & 17 & $(37 \%)$ & $(87 \%)$ \\
\cline { 2 - 13 } F17-B & 0 & $(0 \%)$ & 2 & $(6 \%)$ & 11 & $(31 \%)$ & 16 & $(46 \%)$ & 6 & $(17 \%)$ & $(63 \%)$ \\
F17-C & 0 & $(0 \%)$ & 8 & $(9 \%)$ & 17 & $(20 \%)$ & 34 & $(40 \%)$ & 26 & $(31 \%)$ & $(71 \%)$ \\
S18-A & 0 & $(0 \%)$ & 2 & $(5 \%)$ & 12 & $(28 \%)$ & 24 & $(56 \%)$ & 5 & $(12 \%)$ & $(67 \%)$ \\
S18-B & 0 & $(0 \%)$ & 1 & $(3 \%)$ & 4 & $(10 \%)$ & 16 & $(40 \%)$ & 19 & $(48 \%)$ & $(88 \%)$ \\
S18-C & 0 & $(0 \%)$ & 0 & $(0 \%)$ & 5 & $(29 \%)$ & 5 & $(29 \%)$ & 7 & $(41 \%)$ & $(71 \%)$ \\
S18-D & 0 & $(0 \%)$ & 0 & $(0 \%)$ & 1 & $(6 \%)$ & 10 & $(56 \%)$ & 7 & $(39 \%)$ & $(94 \%)$ \\
S18-E & 2 & $(12 \%)$ & 4 & $(24 \%)$ & 5 & $(29 \%)$ & 3 & $(18 \%)$ & 3 & $(18 \%)$ & $(35 \%)$ \\
\cline { 2 - 11 } TOTAL & 3 & $(1 \%)$ & 17 & $(5 \%)$ & 64 & $(18 \%)$ & 161 & $(45 \%)$ & 109 & $(31 \%)$ & $(76 \%)$ \\
\hline
\end{tabular}

17. Counting this course, how many biology courses have you had at the college level?

\begin{tabular}{|c|c|c|c|c|c|c|c|c|c|c|c|c|}
\hline \multirow[b]{2}{*}{ S17 } & \multicolumn{2}{|c|}{0} & \multicolumn{2}{|c|}{1} & \multicolumn{2}{|c|}{2} & \multicolumn{2}{|c|}{3} & \multicolumn{2}{|c|}{4} & \multicolumn{2}{|c|}{$5+$} \\
\hline & 7 & $(10 \%)$ & 47 & $(67 \%)$ & 11 & $(16 \%)$ & 0 & $(0 \%)$ & 2 & $(3 \%)$ & 3 & $(4 \%)$ \\
\hline F17-A & 3 & $(7 \%)$ & 32 & $(70 \%)$ & 4 & $(9 \%)$ & 1 & $(2 \%)$ & 3 & $(7 \%)$ & 3 & $(7 \%)$ \\
\hline F17-B & 1 & $(3 \%)$ & 28 & $(80 \%)$ & 2 & $(6 \%)$ & 3 & $(9 \%)$ & 0 & $(0 \%)$ & 1 & $(3 \%)$ \\
\hline F17-C & 10 & $(12 \%)$ & 54 & $(64 \%)$ & 18 & $(21 \%)$ & 3 & $(4 \%)$ & 0 & $(0 \%)$ & 0 & $(4 \%)$ \\
\hline S18-A & 6 & $(14 \%)$ & 27 & $(61 \%)$ & 9 & $(20 \%)$ & 2 & $(5 \%)$ & 0 & $(0 \%)$ & 0 & $(5 \%)$ \\
\hline S18-B & 0 & $(0 \%)$ & 30 & $(77 \%)$ & 8 & $(21 \%)$ & 0 & $(0 \%)$ & 0 & $(0 \%)$ & 1 & $(3 \%)$ \\
\hline S18-C & 0 & $(0 \%)$ & 16 & $(94 \%)$ & 1 & $(6 \%)$ & 0 & $(0 \%)$ & 0 & $(0 \%)$ & 0 & $(0 \%)$ \\
\hline S18-D & 0 & $(0 \%)$ & 14 & $(78 \%)$ & 3 & $(17 \%)$ & 0 & $(0 \%)$ & 0 & $(0 \%)$ & 1 & $(6 \%)$ \\
\hline S18-E & 0 & $(0 \%)$ & 15 & $(88 \%)$ & 2 & $(12 \%)$ & 0 & $(0 \%)$ & 0 & $(0 \%)$ & 0 & $(0 \%)$ \\
\hline TOTAL & 27 & $(8 \%)$ & 248 & $(70 \%)$ & 56 & $(16 \%)$ & 9 & $(3 \%)$ & 5 & $(1 \%)$ & 9 & $(3 \%)$ \\
\hline
\end{tabular}

semesters (fall of 2013 through spring of 2017 in Table 1, spring of 2017 through spring of 2018 in Table 2) were of the opinion that they had learned some biology through the Devotional Biology text. But the same students were also of the opinion that they grew in their understanding and relationship with God, felt they could better understand their Christian responsibility to the creation, could better defend their faith, could better worship and/or glorify God, could better recognize God in the creation, were stronger in the faith, could better witness to unbelievers, and could better appreciate the creation.

Student surveys suggest that Devotional Biology is an effective textbook for teaching a biblical perspective of the biological world.

\section{ACKNOWLEDGMENTS}

We would like to thank the anonymous reviewers of our paper for the helpful comments. We would also like to thank the many students who reviewed the text in our various institutions.

\section{REFERENCES}

Wise, K.P. 1998. Is life singularly nested or not? In Proceedings of the Fourth International Conference on Creationism, ed. R.E. Walsh, pp. 619-631. Pittsburgh, Pennsylvania: Creation Science Fellowship.

Wise, K.P. 2005. The nature of God as a curricular theme in biology [abstract]. Occasional Papers of the Baraminology Study Group 5, pp. $16-17$.
Wise, K.P. 2015. Devotional Biology. Cleveland, Georgia: Truett McConnell University.

Wise, K.P., and M.S. Cooper. 1998. A compelling creation: A suggestion for a new apologetic. In Proceedings of the Fourth International Conference on Creationism, ed. R.E. Walsh, pp. 633-644. Pittsburgh, Pennsylvania: Creation Science Fellowship.

\section{THE AUTHORS}

Kurt P. Wise, B.A. (geology, University of Chicago), M.A. \& Ph.D. (paleontology, Harvard University), has been Professor of Natural Science and Director of the Creation Research Center at Truett McConnell University since 2009. Before that he was on the faculty of the Southern Baptist Theological Seminary and Bryan College. Over the last thirty years, Dr. Wise has been active in the development of creation biology and geology, including baraminology, catastrophic plate tectonics, and the founding of the Creation Biology Society and the Creation Geology Society.

Joseph Francis is a professor of biology at the Master's University and assistant professor of general studies at Liberty University. His research interests and publications are in the areas of general biology, invertebrate biology, microbiology, immunology, biology teaching, and bioethics. He currently serves as the dean of the school of science, mathematics, technology and health at the Master's University. He also serves as a board member of the 
Creation Biology Society.

Neal Doran is professor of biology and director of Bryan College's Center for Creation Research (CRC), in Dayton, Tennessee. Prior to coming to Bryan he taught at Patrick Henry College. He is a founding member of the Creation Biology Society and member of the Creation Geology Society. His graduate training is in paleontology (Ph.D., geology) and the History of Science (M.A.). At Bryan College he teaches courses on biology, geology and the philosophy of science.

Andrew J. Fabich earned his B.S. in molecular genetics from The Ohio State University and his Ph.D. in microbiology from the University of Oklahoma. He joined the faculty at Truett McConnell University in 2016. He has widely published on what Escherichia coli does to colonize the mammalian intestine. Specifically, Andrew works on the molecular mechanisms involved with how E. coli adapts to intestinal colonization using a genomics approach. His active research involves other related pathogens that model gastroenteritis like Citrobacter rodentium. Frequently, Andrew works with various creationist organizations and is a member of the American Society for Microbiology.

Stephanie Hartz received her Ph.D. in Molecular and Cellular Biology from University of Maryland at Baltimore County in 1999. While completing her dissertation she taught Genetics and Cell Biology as a Visiting Assistant Professor at James Madison University from 1998 to 1999 . For the last eighteen years she has been at Bryan College and currently serves as Professor of Biology teaching courses which include Introductory Biology for NonMajors, Genetics, Cell Biology, Microbiology, Immunology, and Molecular and Cellular Biology Research.

Tom Hennigan gave up on philosophical naturalism and embraced Christ as his Savior 40 years ago. His training has focused on forest ecology and education. He has an A.A.S. in Forest Technology, a B.S. in Natural Resources Management, an M.S. in Education, and an M.P.S. in Environmental and Forest Biology. Tom has been married to his wife Jennifer for 30 years and has four grown children and four grandchildren. He is currently an Associate Professor of Organism Biology at Truett McConnell University (Cleveland, Georgia) and is active in pastoral care at his church. 